\title{
Adjectives in translation: an experimental study of cognitive links
}

Barbara Gawronska

Dept. of Modern Languages and Translation, University of Agder, Norwy

https://doi.org/10.36505/ExLing-2012/05/0031/000237

\begin{abstract}
The study presents results of an association test focused on adjectives and related to translation of literary prose. The goal is to investigate whether modernization of language in translation leads to better comprehension. The stimuli used in the experiment are adjectives from two Polish translation of the same English novel: one contemporary translation, and one published in 1912.
\end{abstract}

Adjective semantics, translation, equivalence, psycholexicology

\section{Introduction and Goal}

Word association tests have been used as a tool for investigating the organization of the mental lexicon - a study field that Miller and Johnson-Laird (1976) have proposed to call psycholexicology.

"The lexical organization of adjectives is unique to them, and differs from that of the other major syntactic categories", as stated in (Miller et al. 1993:26). While the most important lexical relation between nouns and verbs seems to be hypo-/hypernymy (called "troponymy" in the case of verbs), descriptive adjectives are supposed to be organized into clusters of semantically similar (close to synonyms) entries, which in turn are related to clusters of antonyms. For relational adjectives (adjectives that do not have antonyms) connections to nouns having features denoted by the adjective are claimed to be crucial (Fellbaum 1995, Gross and Miller 1990, Gawronska and Erlendsson 2001).

In translation of literary prose, the right choice of adjectives is of high importance, since a translation equivalent that triggers wrong associations may destroy the artistic effect; as a consequence, functional equivalence between the source and the target text will not be achieved.

The goal of the current study was to investigate Polish translation equivalents of English adjectives in two versions of an English novel: from 1912 and 2003. The main questions was: are the adjectives chosen by the contemporary translator better cognitively anchored in the mental lexicons of the young Polish readers than the adjectives in the old translation? The method used in search for answer to these questions was association test.

\section{Experiment Design}

As stimuli for the association test, 30 Polish adjectives were chosen from two translations of the novel "Anne of Green Gables" by

ExLing 2012: Proceedings of 5th Tutorial and Research Workshop on Experimental Linguistics, 27-29 August 2012, Athens, Greece 
L. M. Montgomery, first published 1908. The first translation into Polish, later referred to as TT1 (target text1), by R. Bernsteinowa, occurred 1912; the second one (TT2), by A. Kuc, was published 2003. The adjectives were chosen from first two chapters of the books, with focus on phrases, where the two translators have used different adjectives in the same context. The stimuli are shown in Table 1, along with the original adjectives and their collocates from the source text (ST).

The informants were 111 children, $49 \%$ girls and $51 \%$ boys, all of them native speakers of Polish, aged 12-13 (which corresponded to the age of the intended receivers of the novel). The data were collected in school classrooms. The pupils received instructions to write down the first word that will occur in their mind when seeing the word on the slide. The adjectives were presented on Power Point slides, one at time, in 15-20 seconds intervals.

Table 1. Adjectives and their collocates from the source text, and their equivalents in TT1 and TT2.

\begin{tabular}{|l|l|l|l|}
\hline \hline ST Noun & ST Adj & TT1 Adj & TT 2 Adj \\
\hline brook & headlong, intricate & $\begin{array}{l}\text { swawolny, } \\
\text { kapryśny }\end{array}$ & wartki \\
\hline stream & quiet & spokojny & cichy \\
\hline stream & well-conducted & dobrze ułożony & spokojny \\
\hline willow & great & wysoki & rozłożysty \\
\hline birch & slender & smukły & wysmukły \\
\hline bloom & filmy & puszysty & delikatny \\
\hline tree & weeny-teeny & nędzny & marny \\
\hline chorus & mournfully sweet & melancholijny & żałobny \\
\hline gulf & dark blue & szafirowy & granatowy \\
\hline tree & huge & wielki & potężny \\
\hline Lombardies & prim & 0 & strzelisty \\
\hline sky & purple & purpurowy & fioletowy \\
\hline water & crocus & szafranowy & 0 \\
\hline veil & misty & koronkowy & lekki \\
\hline mists & pearl & opalowy & fioletowy \\
\hline plumes & nodding & zwiewny & powiewny \\
\hline orchard & beautiful & cudny & 0 \\
\hline \hline
\end{tabular}


Adjectives in translation: an experimental study of cognitive links

\section{Analysis and Results}

The responses were classified according to semantic and phonetic criteria. Six main groups were identified:

1. Synonyms or adjectives close to synonyms

2. Antonyms

3. Nominal collocates

4. Nominalizations or synonyms to nominalizations of the stimulus adjective

5. Phonetically (not semantically) motivated associations

6. Associations that were not possible to interpret and cases of zero response.

Table 2. Associations to adjectives from the two translations (in \%).

\begin{tabular}{|l|l|l|l|l|l|l|}
\hline $\begin{array}{l}\text { Stimulus } \\
\text { adjective }\end{array}$ & Synonym & Antonym & $\begin{array}{l}\text { Nominal } \\
\text { collocate }\end{array}$ & Nominalization & $\begin{array}{l}\text { Phonetic } \\
\text { link }\end{array}$ & Uninterpretable \\
\hline & & & & & & \\
\hline TT1 & 26.2 & 1.3 & 35.5 & 1.7 & 4.0 & 31.3 \\
\hline TT2 & 23.9 & 0.7 & 33.4 & 2.0 & 5.5 & 34.5 \\
\hline
\end{tabular}

Table 3. Adjectives displaying a high percentage of phonetic associations (examples).

\begin{tabular}{|l|l|l|l|l|l|l|}
\hline $\begin{array}{l}\text { Stimulus } \\
\text { adjective }\end{array}$ & Synonym & Antonym & $\begin{array}{l}\text { Nominal } \\
\text { collocate }\end{array}$ & Nominalization & $\begin{array}{l}\text { Phonetic } \\
\text { link }\end{array}$ & Uninterpretable \\
\hline opalowy & 1 & 0 & 12 & 0 & 28 & 59 \\
\hline granatowy & 9 & 1 & 35 & 0 & 22 & 33 \\
\hline strzelisty & 8 & 0 & 10 & 0 & 32 & 50 \\
\hline powiewny & 6 & 0 & 31 & 0 & 18 & 45 \\
\hline
\end{tabular}

The results of the association test (Table 2 and 3) confirm the claim that the strongest cognitive links that constitute the meaning of an adjective are connections to synonymous adjectives and to nominal collocates. The importance of antonyms in the mental semantic network is not confirmed by the current results.

There was no significant difference in the average percentage of uninterpretable answers/no answers between the two groups of adjectives: $31.3 \%$ for TT 1 and $34.5 \%$ and TT2. The average percentage of associations based on phonetic features is slightly higher $(5.5 \%)$ for adjectives from TT2 than for those from TT1 (4\%). High (above the average) percentage of uninterpretable answers or no answers correlate with presence of phonetic associations among the responses given to the adjective. The correlation is statistically significant, on the verge of being strong, despite the limited number of lexemes in the study $(\mathrm{r}=.667, \mathrm{p}=.01)$. 
Semantically odd answers or lack of answers, as well as problems with finding synonyms indicate that the informant does not feel sure about the meaning of the word in question, i.e. that the word's semantic links to other entries in the mental lexicon are few and/or week. Instead of "deep", semantic associations, form-related associations occur in such cases. The lack of evident statistical differences between TT1 and TT2 with respect to the proportions between semantically based response and semantically unmotivated associations indicates that the adjectives used in the older translation are in general quite well cognitively anchored in the mental lexicon of the young speakers of Polish. Thus, the modernization of language performed by the contemporary translator does not seem to have any important effect on the comprehensibility of the adjective phrases. Nevertheless, the modern translator was no doubt right when she decided to omit or replace certain adjectives, used in the older translation (szafranowy, opalowy, swawolny), since these lexemes seem not to be fully intelligible to the young readers.

\section{References}

Fellbaum, C. 1995. Co-occurrence and antonymy. International Journal of Lexicography 8 (4), 28-303.

Gawronska, B. and Erlendsson, B. 2001. Reducing ambiguity by cross-category connections. Proceedings of the NAACL 2001 Workshop on WordNet and Other Lexical Resources, Pittsburgh, U.S.

Gross, D. and Miller, K. J. Adjectives in WordNet. 1990. International Journal of Lexicography 3 (4), 265 - 277

Miller, G. A., Fellbaum, C., and Miller, K.J. 1993. 'Five papers on WordNet. ftp://ftp.cogsci.princeton.edu/pub/wordnet/5papers.ps.

Miller, G. A., and Johnson-Laird, P. N. (1976). Language and Perception. Belknap Press

Montgomery, L.M. 1908. Anne of Green Gables. London, Pittman.

Montgomery, L.M. 1956. Ania z Zielonego Wzgórza. Warszawa, Nasza Księgarnia.

Montgomery, L.M. 2003. Ania z Zielonego Wzgórza. Kraków, Wydawnictwo Literackie. 